Scientific article

Volumen 32(2):339-355. Mayo-agosto, 2021

e-ISSN 2215-3608, doi:10.15517/am.v32i2.42066

https://www.revistas.ucr.ac.cr/index.php/agromeso

\title{
Categorization of the water status of rice inoculated with arbuscular mycorrhizae and with water deficit $^{1}$
}

\section{Categorización del estado hídrico del arroz inoculado con micorrizas arbusculares y con déficit hídrico}

\author{
Michel Ruiz-Sánchez ${ }^{2}$,Juan Adriano Cabrera-Rodríguez z, José M. Dell'Amico-Rodríguez², \\ Yaumara Muñoz-Hernández, Ricardo Aroca-Álvarez, Juan M. Ruiz-Lozano ${ }^{4}$
}

1 Reception: June $8^{\text {th }}, 2020$. Acceptance: September $16^{\text {th }}, 2020$. This work was part of the PhD. thesis "Behavior of rice (Oryza sativa L.) inoculated with arbuscular micorrhyzal fungi and exposed to different water conditions in the soil". Funded by Agencia Española de Cooperación Internacional para el Desarrollo (AECID) (Grant MAE-AECID 2008/09 260940).

2 National Institute of Agricultural Science (INCA9), Scientific and Technological Unit "Los Palacios", Gaveta Postal 1, San Jose de las Lajas, 37200, Mayabeque, Cuba. mich@inca.edu.cu (Corresponding Author: http://orcid.org/0000-0002-7406-4715); nani@inca.edu.cu (http:// orcid.org/0000-0002-0850-9050); josemdellamico@gmail.com (https://orcid.org/0000-0002-8196-2839).

3 Municipal University Center "Los Palacios”, Pinar del Río, Cuba. yaumara@upr.edu.cu (https://orcid.org/0000-0001-9917-4796).

4 Zaidín Experimental Station (CSIC), Department of Soil Microbiology and Symbiotic Systems. Professor Albareda n ${ }^{\circ}$ 1, E-18008 Granada, Spain.raroca@eez.csic.es (https://orcid.org/0000-0003-2402-2063), juanmanuel.ruiz@eez.csic.es (https://orcid.org/0000-0002-4473-5434).

\begin{abstract}
Introduction. The water deficit negatively affects rice plants and limits their productivity. Arbuscular mycorrhizal symbiosis has been shown to improve rice productivity in drought conditions. Objective. To propose a new categorization for the state of water stress of rice plants inoculated (AM) or not with arbuscular mycorrhizal fungi (nonAM) and exposed to water deficit (D) during the vegetative phase. Materials and methods. The experiment was carried out under controlled greenhouse conditions during the years 2009 and 2010 at the Zaidín Experimental Station, Granada, Spain. The rice transplantation was carried out fourteen days after germination to pots with a $5 \mathrm{~cm}$ water sheet and at 30,40, or 50 days after transplantation (DAT) they were subjected to water deficit during a period of 15 days, at which time the water sheet was restored. The control treatment was maintained throughout the cycle under flood conditions (ww). Evaluations were performed at 45, 55, 65 DAT and after recovery at 122 DAT. The harvest was carried out at 147 DAT. Results. The reduction in water supply demonstrated water stress in the plants, manifested by the decrease in the water potential of the leaves. Arbuscular mycorrhizal symbiosis always favored the water status of the plant. Four categories of water status of plants were proposed taking into account water potentials and agricultural yield: no stress ( $\geq-0.67 \mathrm{MPa}$ ); light stress $(<-0.67$ to $-1.20 \mathrm{MPa})$; moderate stress $(<-1.20$ to -1.60 $\mathrm{MPa})$, and severe stress $(<-1.60 \mathrm{MPa})$. Conclusion. The categorization of stress due to the water deficit is a tool of high scientific value for the specific case of rice, since this plant has the capacity to adapt to tolerate the presence of a sheet of water throughout its biological cycle and is highly susceptible to water deficit.
\end{abstract}

Keywords: drought, agricultural yield, Oryza sativa.

\section{Resumen}

Introducción. El déficit hídrico afecta negativamente a las plantas de arroz y limita su productividad. Se ha demostrado que la simbiosis micorrízica arbuscular mejora la productividad del arroz en condiciones de sequía. 
Objetivo. Proponer una nueva categorización para el estado de estrés hídrico de las plantas de arroz inoculadas (MA) o no con hongos micorrízicos arbusculares (noMA) y expuestos al déficit hídrico (D) durante la fase vegetativa. Materiales y métodos. El experimento se llevó a cabo bajo condiciones controladas de invernadero durante los años 2009 y 2010 en la Estación Experimental del Zaidín, Granada, España. El trasplante del arroz se realizó catorce días después de la germinación a macetas con una lámina de agua de $5 \mathrm{~cm}$ y a los 30, 40 o 50 días después del trasplante (DAT) se sometieron a déficit hídrico durante un período de quince días, momento en que se restableció la lámina de agua. El tratamiento de control se mantuvo durante todo el ciclo en condiciones de inundación (ww). Las evaluaciones se realizaron a los 45,55, 65 DAT y después de la recuperación a 122 DAT. La cosecha se efectuó a los 147 DAT. Resultados. La reducción del suministro de agua evidenció estrés hídrico en las plantas, manifestado por la disminución del potencial hídrico de las hojas. La simbiosis micorrízica arbuscular siempre favoreció el estado hídrico de la planta. Se propusieron cuatro categorías de estado hídrico de plantas teniendo en cuenta los potenciales hídricos y el rendimiento agrícola: sin estrés ( $\geq-0,67 \mathrm{MPa})$; estrés ligero $(<-0,67$ a $-1,20 \mathrm{MPa})$; estrés moderado (<1,20 a -1,60 MPa) y estrés severo (<-1,60 MPa). Conclusión. La categorización del estrés debido al déficit hídrico es una herramienta de alto valor científico para el caso específico del arroz, ya que esta planta tiene la capacidad de adaptación para tolerar la presencia de una lámina de agua durante todo su ciclo biológico y es altamente susceptible al déficit hídrico.

Palabras clave: sequía, rendimiento agrícola, Oryza sativa.

\section{Introduction}

The ongoing climate change is characterized by increased temperatures and altered precipitation patterns. In addition, there has been an increase in both the frequency and intensity of extreme climatic events such as drought (Field et al., 2014; Brunner et al., 2015). Moreover, the global climate change is contributing to spread the water deficit problems to regions where drought was negligible in the past (Trenberth et al., 2014). Water deficit is considered the most important abiotic factor limiting plant growth and yield in many areas (Bray, 2004; Trenberth et al., 2014). The severity of drought depends on many different factors including evaporative demands, rainfall levels and moisture-storing capacity of soils (Farooq et al., 2014). Drought stress has now become a severe threat to ensure food security in the developing world.

In plants, drought induces biochemical, physiological, morphological, and molecular changes. Thus, most plant processes are affected directly or indirectly by the water limitation (Ruiz-Lozano et al., 2012). Different plant species vary in their sensitivity and response to water deficit, although it is assumed that all plants have encoded capability for stress perception, signaling and response (Bohnert et al., 1995, Golldack et al., 2014). Plants have developed several mechanisms to cope with drought stress such as morphological adaptations, osmotic adjustment, optimization of water resources, improvement of antioxidant system, reduction of growth and photosynthesis rate and stomatal closure, all aimed to optimize water use (Farooq et al., 2009; Osakabe et al., 2014; Ruiz-Lozano et al., 2012; Shinozaki \& Yamaguchi-Shinozaki, 2006).

Rice plays a major role as a staple food, supporting more than three billion people and comprising 50 to $80 \%$ of their daily calorie intake (Khush, 2003). The demand for rice production is still rising because of the continuous increase in world population. The world population is predicted to reach approximately 8 billion by 2030 , and there is therefore a need to further increase rice production by $40 \%$ in the next 20 years (Bernier et al., 2008). However, drought stress severely impairs its production. Worldwide, drought affects approximately 23 million hectares of rainfed rice (Serraj et al., 2011). This cereal requires larger amount of water throughout its life cycle as compared to other crops. Hence, water stress causes severe threat to rice production, with drought being a major challenge 
limiting rice production. This cereal requires larger amount of water throughout its life cycle as compared to other crops. Hence, water stress causes severe threat to rice production, with drought being a major challenge limiting rice production. It has been estimated that more than $50 \%$ of the world's arable land will be affected by drought in the year 2050 (Singhal et al., 2016). The increase in drought severity coupled with lack of high-yielding genotypes that are suitable for cultivation under drought conditions are the most limiting factors responsible for low production of rice. Rice cultivation is seasonal due to a lack of appropriate rice cultivars and techniques (Oladosu et al., 2019).

The rice crop has the peculiarity to be a semi-aquatic plant; however, it is traditionally cultivated in continuous flooding conditions for most of its development cycle (Hattori et al., 2011). Although rice plants have few adaptations for limited water supply conditions and it is sensitive to drought (Kamoshita et al., 2008), the exposure of the crop to water deficit in the vegetative phase has favored the increase of yield, as reported by different researchers (García et al., 2009; Polón, 2007).

Crop responses to drought stress and its tolerance level can be measured by monitoring different physiological changes during drought period. Taking into account the current and future forecast of water scarcity and the importance of rice crop, it is necessary to explore the potential of the application of water deficit periods in order to keep or improve rice production, as well as, knowing the water potential of rice plants when expresses its maximum yield potential. Under conditions of water deficit, plants tend to control root water uptake and/or tissue water status by adjusting root hydraulic conductivity and osmotic adjustment to maintain a gradient of water potential favorable to plant entrance into the root (Bárzana et al., 2012), at the same time that it favors the leaf water potential of plant.

The leaf water potential allows measuring the plant water status during the day. It is a method which enables the measurement of a short-term hydric response (for example on an hourly basis) of plant in reaction to a change in the root water absorption and the leaf transpiration (interaction soil water content $\mathrm{x}$ climate $\mathrm{x}$ leaf transpiration $\mathrm{x}$ cultivar). The leaf water potential is a variable of great reliability and used to describe the water status of a plant (Azcón-Bieto \& Talón, 2000; Taiz \& Zeiger, 2006), this variable is taken as a reference for all the agricultural cultivations of interest, including rice.

With the purpose of estimating the hydric state of the plants, other physiological parameters indicative of it have been carried out, such as perspiration and stomatal conductance, $\mathrm{CO}_{2}$ assimilation, respiration, cell growth and cell division of cell synthesis, hormones and ethylene, nitrogen metabolism, enzyme levels and mechanisms underlying responses to water stress (Hsiao, 1973). It is important to note that the Hsiao (1973) proposed moderate water deficit category included a very broad range ranging from -5 bar to -12 or -15 bar ( $=-0.5 \mathrm{MPa}$ to -1.2 or $-1.5 \mathrm{MPa}$ ), and in this work it was possible to determine and establish another range of water stress. In spite of the above, from the 1970s to the present, several authors have used the categorization proposed by this author to compare their results, which was recently used in research on rice by García et al. (2009).

Studies by Carbonneau (1998) suggest threshold values or critical levels of water potential in the case of vine cultivation, based on the result of 20 or more years of observations in many vineyards of different cultivars. This reliable and validated tool is conducive to appropriate sampling at the plot level (Deloire \& Heyns, 2011). It is considered critical level in the plants at physiological level, all those abiotic factors that affect their growth and development, which by excess or by default cause the decrease of their yield. There are critical levels of temperature, light, oxygen, carbon dioxide, soil, availability of water and nutrients, which affect physiological processes such as; photosynthesis, respiration, perspiration, absorption of water and nutrients, among others. (Azcón-Bieto \& Talón, 2000; Degrovani et al., 2010; Taiz \& Zeiger, 2006).

Several studies have described how mycorrhizal symbiosis favors the water status of various plant species in the presence of a water deficiency in the soil (Aroca et al., 2008); that these microorganisms contribute to increase relative water content, transpiration rate, and $\mathrm{CO}_{2}$ exchange (Bárzana et al., 2015; Ruiz-Sánchez et al., 2010; RuizLozano et al., 2012; Ruiz-Sánchez et al., 2015), thus ensuring a better water status of plant. 
The objective of the present work was to propose a new categorization for the state of water stress of rice plants inoculated (AM) or not with arbuscular mycorrhizal fungi (non $\mathrm{AM}$ ) and exposed to water deficit (D) during the vegetative phase.

\section{Materials and methods}

\section{Experimental design}

The experiment was carried out under controlled greenhouse conditions in 2009 and 2010, at the Zaidin Experimental Station, Consejo Superior de Investigaciones Cientificas (CSIC), Granada, Spain, with rice plants (Oryza sativa) cv. INCA LP-5 (Pérez et al., 2018). The rice plants were exposed to water stress at three different times in the vegetative phase, following a completely randomized experimental design, with five replications.

\section{Treatments}

T1. Plants condition under well-watered (ww).

T2. Plants under water stress or drought (D) at 30 days after the transplant (DAT).

T3. Plants condition under well-watered (ww).

T4. Plants under water stress or drought (D) at 40 days after the transplant (DAT).

T5. Plants condition under well-watered (ww).

T6. Plants under water stress or drought (D) at 50 days after the transplant (DAT).

\section{Soil and biological materials}

A seedbed of rice was set in plastic trays of $0.40 \times 0.80 \times 0.08 \mathrm{~m}$ with sterile sand. Fourteen days old rice seedlings were transplanted, single plant to each of the $1 \mathrm{~kg}$ pots $(0.18 \mathrm{~m}$ high and $0.13 \mathrm{~m}$ diameter $)$ containing a substrate composed of sand (granulometry $<1 \mathrm{~mm}$ ) and soil (granulometry $<5 \mathrm{~mm}$ ) in a 1:1 ratio (v:v), which was previously sterilized. The sand was sterilized at $120^{\circ} \mathrm{C}$ for $20 \mathrm{~min}$ in a Selecta autoclave; model PRESOCLAVEII $75 \mathrm{~L}$, while the soil was sterilized by steaming at $95-100{ }^{\circ} \mathrm{C}$, for $60 \mathrm{~min}$ on three consecutive days. The soil (collected from the Zaidin Experimental Station, Granada, Spain) had a pH of 8.1 (water); $1.81 \%$ organic matter, nutrient concentrations $\left(\mathrm{mg} \mathrm{kg}^{-1}\right)$ : N, 2.5; P, 6.2 ( NaHCO extractable $\left.\mathrm{P}\right) ; \mathrm{K}, 132.0$. The soil texture was made up of $35.8 \%$ sand, $43.6 \%$ silt, and $20.5 \%$ clay.

Mycorrhizal inoculum was bulked in an open-pot culture of Zea mays L. and consisted of soil, spores, mycelia and infected root fragments. The AM species was Rhizoglomus intrarradices (Schenck and Smith), isolate EEZ 01 (56 spores $\mathrm{g}^{-1}$ of inoculum). Prior to transplantation, plants were inoculated with Rhizoglomus intrarradices, at a rate of $5 \mathrm{~g}$ of inoculum per pot, deposited under the plant. $50 \%$ of them were inoculated, while the other $50 \%$ remained non-inoculated. These no-inoculated control treatments (nonAM) received a $10 \mathrm{ml}$ aliquot of filtrate $(<20$ $\mu \mathrm{m}$ ) of the AM inoculates to provide a general microbial population free of AM propagules.

\section{Growing conditions}

The pots were placed in the greenhouse where the seedbed was established and remained throughout the experiment with temperatures of $26^{\circ} \mathrm{C}$ and $22^{\circ} \mathrm{C}$ (day / night, respectively); relative humidity between 50-70; photoperiod of 16 hours of light and 8 hours of darkness and photosynthetically active radiation of $850 \mu \mathrm{mol} \mathrm{m} \mathrm{m} \mathrm{s}^{-1}$, measured with a 
portable LIQUOR (Lincoln, NE, USA, model LI-188B), following an experimental design completely randomized, with five repetitions, for which 25 pots were used per treatment.

The irrigation consisted of maintaining a $5 \mathrm{~cm}$ sheet of water daily on the surface of the substrate in all the treatments until the different irrigation management was applied. The irrigation treatments consisted in the suspension of the water sheet at 30,40, and 50 days after the transplant (DAT) for a period of 15 days and a treatment without suspension of the water sheet (Control). After the period without water sheet, the water sheet (5 $\mathrm{cm}$ ) was replaced every other day until 15 days before harvest, which was the same at 147 DAT.

The total nutrient application, corresponding to $0.123 \mathrm{~g}$ of $\mathrm{N}, 0.050 \mathrm{~g}$ of $\mathrm{P}_{2} \mathrm{O}_{5}$, and $0.059 \mathrm{~g}$ of K$_{2} \mathrm{O}$ per pot, was performed at 20 DAT (30\% of total dose), 35 DAT (40\% of total dose), and 60 DAT (30\% of total dose). Urea $(46 \% \mathrm{~N})$, triple superphosphate $\left(46 \% \mathrm{P}_{2} \mathrm{O}_{5}\right)$ and potassium chloride $\left(60 \% \mathrm{~K}_{2} \mathrm{O}\right)$ were used as fertilizers.

\section{Measurements}

\section{Soil moisture}

Soil moisture was determined after the suspension period of the water sheet (at 45, 55, and 65 DAT), with a Theta Probe Soil Moisture Sensor - ML2x and was expressed in $\mathrm{cm}^{3}$ of water per $\mathrm{cm}^{3}$ of substrate.

\section{Mycorrhizal colonization}

The percentage of mycorrhizal root infection was estimated by visual observation of fungal colonization after clearing washed roots in $10 \% \mathrm{KOH}$ and staining with $0.05 \%$ Trypan blue in lactic acid (v/v), according to Phillips \& Hayman (1970). Quantification of the root colonization was performed according to the grid-line intersect method (Giovannetti \& Mosse, 1980). Five replicates per treatment were used.

\section{Water potential}

Five plants per treatment were taken 15 days after starting the water stress $(45,55$, and 65 DAT) and at 122 DAT (25 days before harvest), for leaf water potential $(\Psi \mathrm{h})$, with the purpose of measuring the values of leaf water potential. The leaf water potential $(\Psi \mathrm{h})$ was determined by the psychrometric method, two hours after the start of the daytime period (between 9:00 a.m. and 10:00 a.m.), using a microvolt meter HR-33T connected to a psychrometric chamber C52 (Wescor Inc, Logan, UT, USA), as described by Porcel \& Ruiz-Lozano (2004). Ten discs (0.005 m diameter) were taken per treatment, that is two per plant from the central part of the leaves of the plant and placed in the chamber for 15 min to stabilize the temperature and water vapor of the disc before read $\Psi \mathrm{h}$, which was expressed in MPa.

\section{Agricultural yield}

Agricultural yield per plant $\left(\mathrm{g} \mathrm{plant}^{-1}\right.$ ) was evaluated at the time of harvest (147 DAT) when $85 \%$ of the spikes in the plant turned yellow (International Rice Research Institute, 2013). The production of the five plants was harvested independently and the production of the grains per plant was weighed. The relative agricultural yield (RR \%) was estimated, dividing the yield values obtained between the maximum yield value and then multiplied by 100 . The values of RR $\%$ were used to determine the critical levels of $\Psi$ h. The critical levels of $\Psi$ h were determined following the mathematical procedure proposed by Cate \& Nelson (1971), considering first all the studied treatments and then subdividing the populations until reaching the stress categories. 


\section{Statistic analysis}

The data were subjected to analysis of simple variance (ANOVA), plants inoculated with arbuscular mycorrhizal fungi (AMF), exposed or not to water stress, from which significant interaction was found between the factors under study, the data were submitted to the Test Duncan's Multiple Range (Duncan, 1955). After the recovery period (at 122 DAT), the data are processed following the same procedure as after each period of water stress (D), with the exception that the values are compared against a single control without water stress (ww).

\section{Results}

No mycorrhizal colonization was observed in plants not provided with AM inoculum due to the sterilization to which the substrate was subjected. The mycorrhizal colonization in rice plants that remained under flooding conditions (ww) and in those that were exposed to drought stress (D), while in the inoculated plants an increase of this variable was found over time (Figure 1).
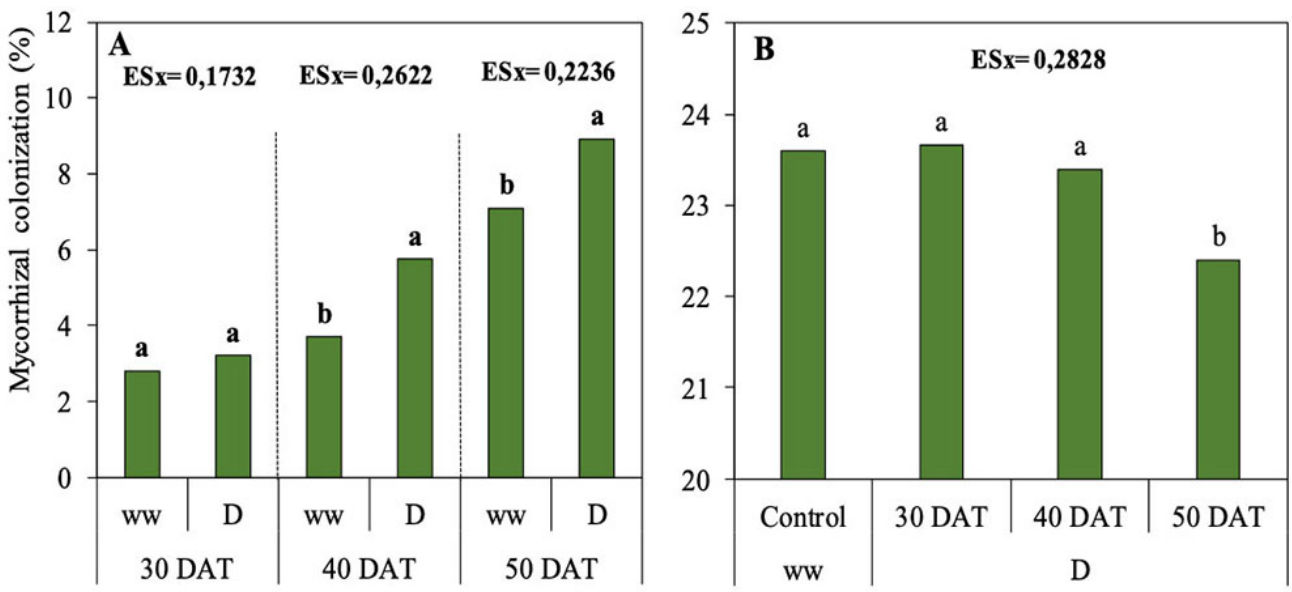

Figure 1. Mycorrhizal colonization, 15 days after starting the reduction of water supply (A) and 25 days before harvest, at 122 days after transplantation (DAT) (B) in rice plants (O. sativa) inoculated with $R$. intrarradices (AM) and non-inoculated (nonAM), cultivated with a sheet of water (ww) or exposed to a reduction of water supply (D) at 30, 40, and 50 DAT, respectively, at the Zaidin Experimental Station, Consejo Superior de Investigaciones Cientificas (CSIC), Granada, Spain. 2009-2010.

Means followed by the same letter are not significantly different $(\mathrm{p}>0.05)$ as determined by Duncan's multiple range test $(\mathrm{n}=5)$.

Figura 1. Colonización micorrízica, 15 días después de comenzar la reducción del suministro de agua (A) y 25 días antes de la cosecha, a 122 días después del trasplante (DAT) (B) en plantas de arroz (O. sativa) inoculadas con $R$. intrarradices (MA) y no inoculadas (noMA), cultivadas con lámina de agua (ww) o expuestas a una reducción del suministro de agua (D) a los 30, 40 y 50 DDT, respectivamente, en la Estación Experimental Zaidín, Consejo Superior de Investigaciones Científicas (CSIC), Granada, España. 2009-2010.

Las medias seguidas de la misma letra no son significativamente diferentes $(\mathrm{p}>0,05)$ según lo determinado por la prueba de rango múltiple de Duncan ( $\mathrm{n}=5)$.

At 45 DAT no significant differences were observed between the plants maintained under flooding conditions (ww) and those exposed to water stress (D); however, at 55 and 65 DAT higher colonization values were observed in treatments that were exposed to water stress. In the recovery at 122 DAT (Figure 1B), the mycorrhizal colonization in the control plants and those that were exposed to water stress at 30 and 40 DAT were similar and in the first two treatments there was more colonization than when the plants were stressed at 50 DAT. 
The above data showed that the largest increase in colonization, between the first evaluation and after recovery was found in stressed plants. In this sense, in stressed plants at 30 DAT the colonization increase was $20 \%$, when the stress was imposed at 40 DAT the increase was $17.5 \%$ and finally, the stress at 50 DAT increased the colonization by $13 \%$, compared to the post-recovery indicator stress assessment (122 DAT).

The results of agricultural yield in rice plants exposed to a reduction of water supply for a period of 15 days during the vegetative phase (30,40 and 50 DAT) and inoculated or not with $R$. intrarradices are shows in the Figure 2. The lowest yield was found in plants that were not exposed to water deficit and were not inoculated. This parameter decreased when the water stress was imposed at 50 DAT, with respect to the treatments that were exposed to this condition at 30 and 40 DAT, although the yield was higher than in the control treatment without water stress (ww).

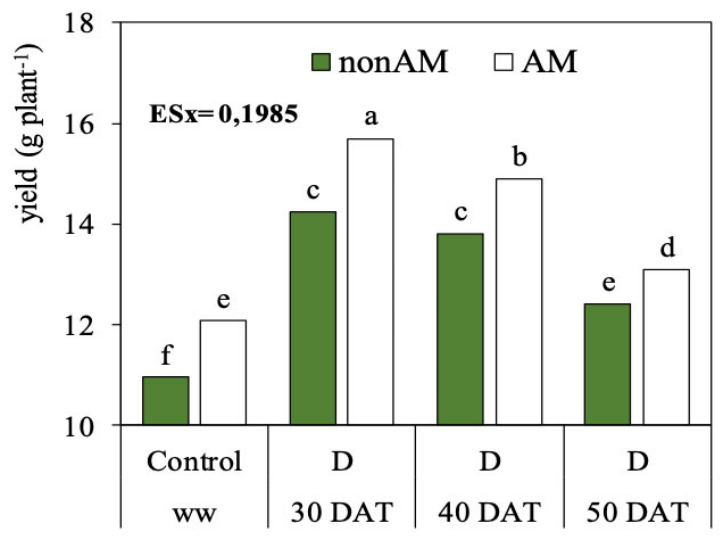

Figure 2. Agricultural yield at the time of harvest (147 DAT) in rice plants (O. sativa) inoculated with $R$. intrarradices (AM) and non-inoculated (nonAM), cultivated with sheet of water (ww) or exposed to a reduction of water supply (D) at 30, 40, and 50 DAT, respectively, at the Zaidin Experimental Station, Consejo Superior de Investigaciones Cientificas (CSIC), Granada, Spain. $2009-2010$.

Means followed by the same letter are not significantly different $(\mathrm{p}>0.05)$ as determined by Duncan's multiple range test ( $\mathrm{n}=5)$. DAT: days after transplantation.

Figura 2. Rendimiento agrícola en el momento de la cosecha (147 DAT) en plantas de arroz (O. sativa) inoculadas con $R$. intrarradices (MA) y no inoculadas (noMA), cultivadas con lámina de agua (ww) o expuestas a una reducción del suministro de agua (D) a los 30, 40 y 50 DDT, respectivamente, en la Estación Experimental Zaidín, Consejo Superior de Investigaciones Científicas (CSIC), Granada, España, 2009-2010.

Las medias seguidas de la misma letra no son significativamente diferentes $(\mathrm{p}>0,05)$ según lo determinado por la prueba de rango múltiple de Duncan (n=5). DAT: días después del trasplante.

The values of the water potential of the leaf $(\Psi \mathrm{h})$ are shown in Figure 3 . The $\Psi \mathrm{h}$ was higher in the plants that did not suffer a reduction of the water supply (ww) in the three moments (30, 40, and 50 DDT). The treatment with the lowest water content in the leaves was that which was exposed to water stress at 50 DDT (Figure 3 A). However, always the inoculation treatments with AM showed the highest values of $\Psi \mathrm{h}$ with respect to the plants without AM.

The period of 15 days of water deficit in the soil (substrate) caused a water stress in the plant, which increased as the water deficit was imposed later, this was reflected in a decrease of $\Psi \mathrm{h}$ (Figure $3 \mathrm{~A}$ ); furthermore, under such conditions of water deficit, the inoculation caused $\Psi \mathrm{h}$ values always higher than those found in non-inoculated plants. After recovery (122 DAT), values greater than $\Psi \mathrm{h}$ in plants inoculated without stress and stressed at 30 DAT compared to the control treatments and those exposed to water stress at 40 and 50 DAT (Figure $3 \mathrm{~B}$ ).

The results so far analyzed indicate that the $\Psi \mathrm{h}$ reflected the water status of the plants exposed or not to water stress, which showed the pertinence of determining the critical levels or values of $\Psi \mathrm{h}$ for rice related to relative yield (RR \%). Since there is still no categorization of specific $\Psi$ h in rice plants exposed to this condition. Figure 4 shows the dispersion of values between $\Psi \mathrm{h}$ and RR \% found in the different conditions evaluated. 


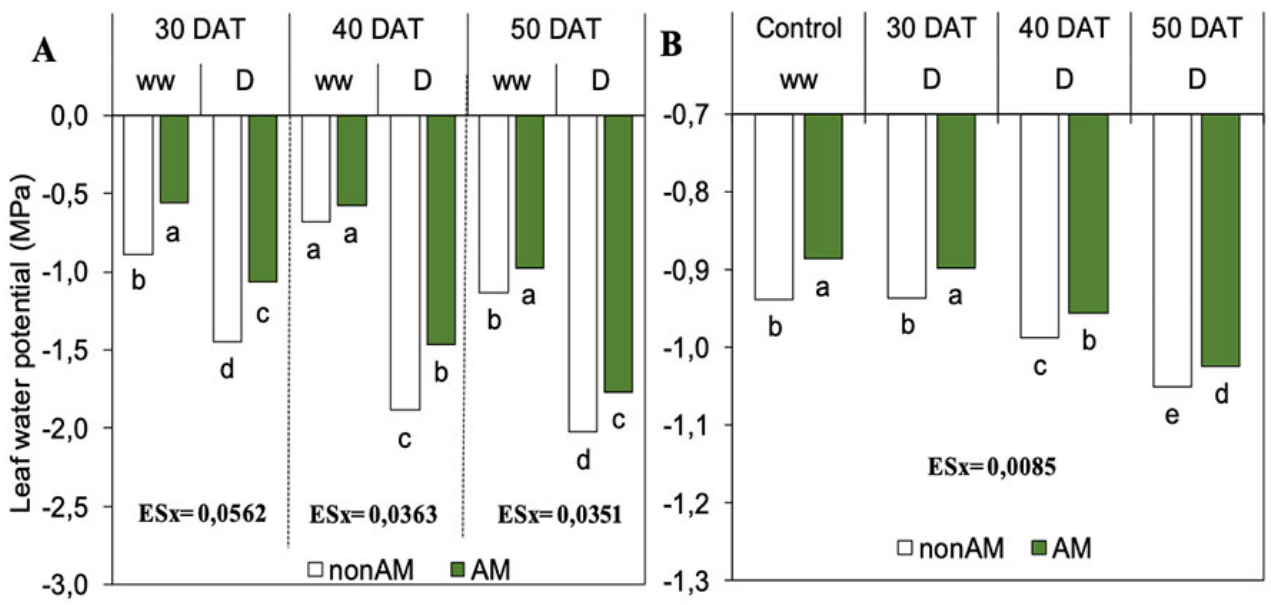

Figure 3. Leaf water potential, 15 days after starting the reduction of water supply (A) and 25 days before harvest (B), in rice plants (Oryza sativa) inoculated with $R$. intrarradices (AM) and non-inoculated (nonAM), cultivated with water sheet (ww) or exposed to a reduction of water supply (D) at 30,40 and 50 DAT, respectively, at the Zaidín Experimental Station, Granada, Spain, $2009-2010$.

Means followed by the same letter are not significantly different ( $\mathrm{p}>0.05)$ as determined by Duncan's multiple range test ( $\mathrm{n}=5)$.

Figura 3. Potencial hídrico de las hojas, 15 días después de comenzar la reducción del suministro de agua (A) y 25 días antes de la cosecha (B), en plantas de arroz (Oryza sativa) inoculadas con $R$. intrarradices (MA) y no inoculadas (noMA, cultivadas con lámina de agua (ww) o expuestas a una reducción del suministro de agua (D) a los 30,40 y 50 DDT, respectivamente, en la estación experimental de Zaidín, Granada, España, 2009-2010.

Las medias seguidas de la misma letra no son significativamente diferentes $(p>0,05)$ según lo determinado por la prueba de rango múltiple de Duncan (n=5). DAT: días después del trasplante.

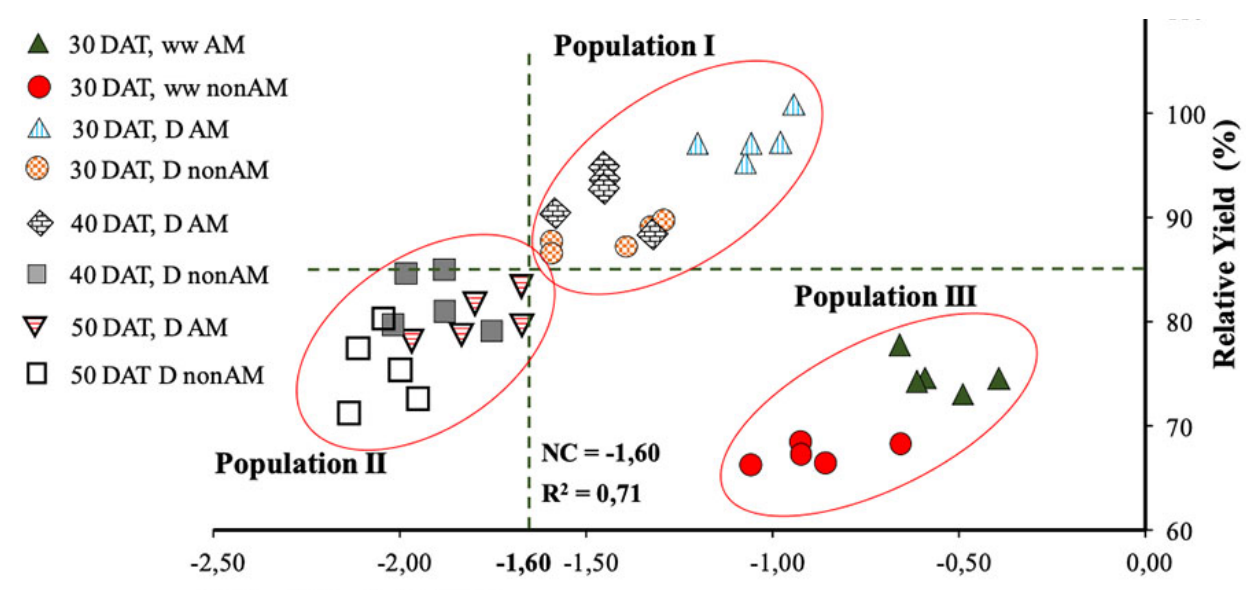

Water Potential (MPa)

Figure 4. Critical level of foliar water potential $(\Psi \mathrm{h})$ determined 15 days after each period of water supply reduction, represented in a scatter diagram of the relationship between $\Psi \mathrm{h}$ and the relative yield of rice plants (Oryza sativa) inoculated with $R$ intrarradices (AM) and non-inoculated (nonAM), cultivated with water sheet (ww) or exposed to a reduction of water supply (D) at 30, 40 and 50 DAT, respectively. The maximum yield with which the relative yield was calculated was $16.24 \mathrm{~g} \mathrm{plant}^{-1}$, at the Zaidín Experimental Station, Granada, Spain, 2009-2010.

Figura 4. Nivel crítico de potencial hídrico foliar $(\Psi \mathrm{h})$ determinado 15 días después de cada período de reducción del suministro de agua, representado en un diagrama de dispersión de la relación entre $\Psi$ h y el rendimiento relativo de las plantas de arroz (Oryza sativa) inoculadas con $R$. intrarradices (MA) y no inoculados (noMA), cultivadas con lámina de agua (ww) o expuestas a una reducción del suministro de agua (D) a los 30,40 y 50 DDT, respectivamente. El rendimiento máximo con el que se calculó el rendimiento relativo fue de 16,24 g planta $^{-1}$, en la Estación Experimental Zaidín, Granada, España, 2009-2010. 
Three well-defined populations were obtained, one in the upper right quadrant, one in the lower left quadrant and the other in the lower right quadrant. The first population was characterized by presenting values of RR $\%$ between 85 and $100 \%$, with a critical level of water potential up to $-1.60 \mathrm{MPa}$, corresponding to plants not inoculated and inoculated with AM that were stressed at 30 DAT and those inoculated with AM and exposed to water stress at 40 DAT.

The second population with a maximum RR of $85 \%$ and a critical water potential level higher than $-1.60 \mathrm{MPa}$, corresponded to non-inoculated treatments exposed to water stress at 40 DAT and not inoculated and inoculated treatments exposed to water stress at 50 DAT. The third population corresponded to not inoculated and inoculated treatments which were never exposed to a stress situation.

The value of RR \% that corresponds to the critical level indicates that the population of the upper right quadrant can be divided again. This second partition (Population I) was characterized by presenting a RR \% of 95 $\%$, associated to the critical level of $\Psi \mathrm{h}-1.20 \mathrm{MPa}$ and corresponded to the treatments exposed to water stress at 30 and 40 DAT, but inoculated with AMF and not inoculated (Figure 5).

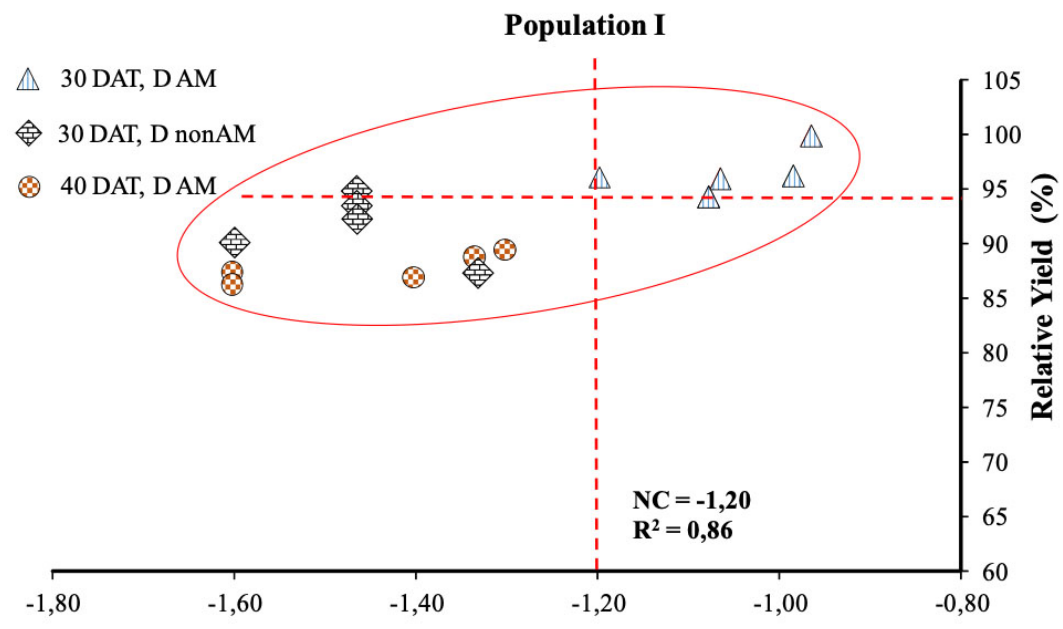

Water Potential (MPa)

Figure 5. Critical level of leaf water potential $(\Psi \mathrm{h})$ determined 15 days after each period of reduction of water supply, represented in a dispersion diagram of the relationship between $\Psi \mathrm{h}$ and the relative yield of rice plants (Oryza sativa) inoculated with $R$. intrarradices (AM) and non-inoculated (nonAM), cultivated with to a reduction of water supply (D) at 30 and 40 DAT, respectively. The maximum yield at which the relative yield was calculated was 16.24 g plant $^{-1}$, at the Zaidín Experimental Station, Granada, Spain, 2009-2010.

DAT: days after transplantation.

Figura 5. Nivel crítico de potencial hídrico foliar $(\Psi$ h) determinado 15 días después de cada período de reducción del suministro de agua, representado en un diagrama de dispersión de la relación entre $\Psi$ h y el rendimiento relativo de las plantas de arroz (Oryza sativa) inoculadas con $R$. intrarradices (MA) y no inoculados (noMA), cultivadas con reducción del suministro de agua (D) a los 30 y 40 DDT, respectivamente. El rendimiento máximo al que se calculó el rendimiento relativo fue de 16,24 g planta ${ }^{-1}$, en la Estación Experimental Zaidín, Granada, España, 2009-2010.

DAT: días después del trasplante.

Finally, the third population formed by witness treatments, which were not subjected to water stress conditions, could be divided into two subpopulations, with a new critical level of $\Psi$ h of $-0.67 \mathrm{MPa}$ (Figure 6).

The analysis developed with the results allowed to establish a categorization of the degree of stress in which the rice plants were found from $\Psi \mathrm{h}$ and RR \% (Table 1). 


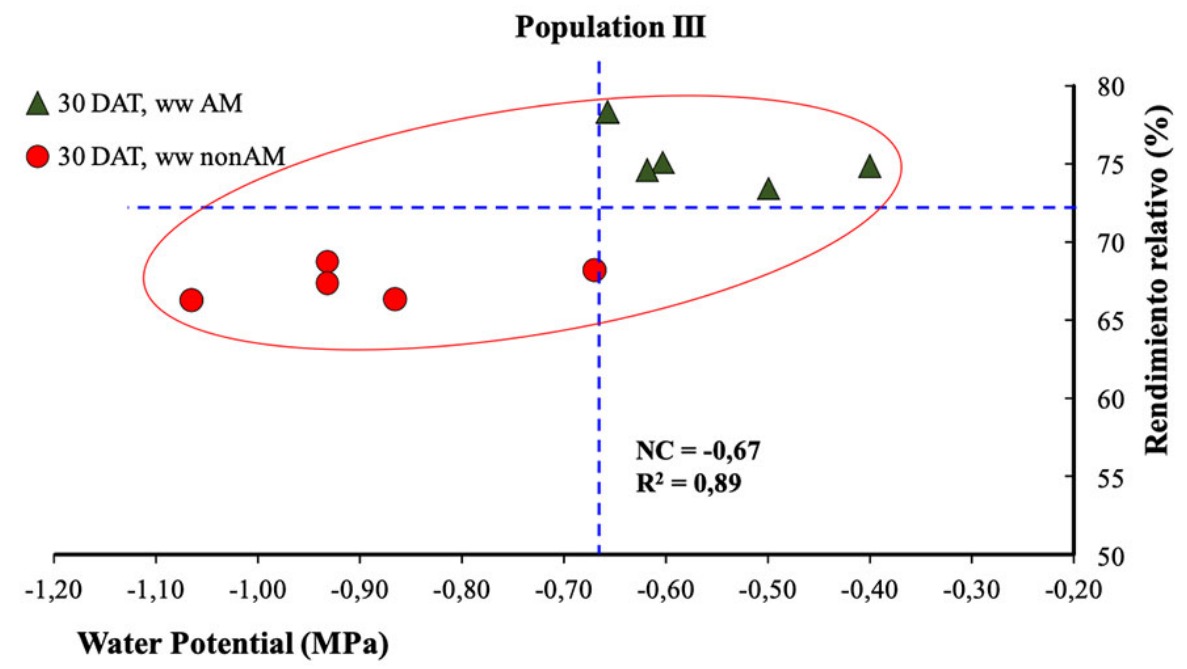

Figure 6. Critical level of leaf water potential $(\Psi \mathrm{h})$ determined 15 days after each period of water supply reduction, represented in a scatter diagram of the relationship between $\Psi \mathrm{h}$ and the relative yield of rice plants (O. sativa) inoculated with $R$. intrarradices (AM) and non-inoculated (nonAM), cultivated under well-watered (ww) conditions, at 30 DAT. The maximum yield at which the relative yield was calculated was $16.24 \mathrm{~g}_{\text {plant }}{ }^{-1}$, at the Zaidin Experimental Station, Consejo Superior de Investigaciones Cientificas (CSIC), Granada, Spain, 2009-2010.

Figura 6. Nivel crítico de potencial hídrico foliar $(\Psi \mathrm{h})$ determinado 15 días después de cada período de reducción del suministro de agua, representado en un diagrama de dispersión de la relación entre $\Psi$ h y el rendimiento relativo de las plantas de arroz $(O$. sativa) inoculadas con $R$. intrarradices (MA) y no inoculados (noMA), cultivados en condiciones bien regadas (ww), a 30 DAT. El rendimiento máximo al que se calculó el rendimiento relativo fue de 16,24 $\mathrm{g}_{\text {planta }}{ }^{-1}$, en la Estación Experimental Zaidín, Consejo Superior de Investigaciones Científicas (CSIC), Granada, España, 2009-2010.

Table 1. Categorization of water deficit stress in rice plants $(O$. sativa) as a function of leaf water potential ( $\Psi$ h) (measured between 9:00 am and 10:00 am) and relative agricultural yield (RR), at the Zaidin Experimental Station, Consejo Superior de Investigaciones Cientificas (CSIC), Granada, Spain, 2009-2010.

Cuadro 1. Categorización del estrés por déficit hídrico en plantas de arroz ( $O$. sativa) en función del potencial hídrico foliar ( $\Psi$ h) (medido entre las 9:00 a.m. y las 10:00 a.m.) y el rendimiento agrícola relativo (RR), en la Estación Experimental Zaidín, Consejo Superior de Investigaciones Científicas (CSIC), Granada, España, 2009-2010.

\begin{tabular}{cc}
\hline Stress category & Ranges of the $\boldsymbol{\Psi}_{\mathbf{h}}(\mathbf{M P a})$ \\
\hline No stress & $\geq-0.67$ \\
Light stress & $<-0.67 \mathrm{a}-1.20$ \\
Moderate stress & $<-1.20 \mathrm{a}-1.60$ \\
Severe stress & $<-1.60$ \\
\hline
\end{tabular}

\section{Discussion}

The values of mycorrhizal colonization reaffirmed the results obtained by other researchers, who found low colonization levels working with the same plant species and under flooding conditions (Vallino et al., 2009; 2014). Despite of the low levels colonization of AM root, AM symbiosis had an influence on $\Psi \mathrm{h}$ and agricultural yield. The most probable cause that could motivate the low levels of mycorrhizal colonization is the anaerobiosis 
condition and the production of ethylene in the medium. The anaerobiosis condition due to the existence of the water sheet, increases the ethylene concentration in the medium (Malik et al., 2003), compound which at high concentrations inhibits hyphal growth (Ishii et al., 1996).

Exposing the rice plant to a reduction of water supply for a period of 15 days at some moments in the vegetative phase guaranteed the increase in agricultural yield. The increases in the development of plants inoculated with arbuscular mycorrhizal fungi (AMF) was also reported by other researchers working on crops such as wheat (Ma et al., 2008), maize (Li et al., 2011), the latter under rainfed conditions and crop rotation with other crops.

The best hydric state of the plant is associated with the increase in $\Psi \mathrm{h}$, while it can be related to mycorrhizal inoculation, from possible hyphal growth, combined with the ability of the fungus to absorb water under low $\Psi \mathrm{h}$ conditions (Augé, 2004; Lehto and Zwiazek, 2011). The increase in $\Psi \mathrm{h}$ in the inoculated plants, led to greater growth and development of the plant, from the improvement of the $\Psi \mathrm{h}$ gradient, which had to facilitate the flow of water to the elongating cells.

It seems that growth hormone exudates in the AMF-plant interaction (Pozo et al., 2015), stimulated greater growth and development observed through agricultural yield. In addition to this, greater efficiency in stomatic control, ways that the plant uses as an adaptation mechanism, to reduce water losses (Damour et al., 2010). RuizSánchez et al. $(2010 ; 2011)$ reported similar results in rice plants exposed to water stress for a period of 15 days in the vegetative phase.

The results of this investigation corroborated the findings of other authors, as regards the increase in rice yield due to the effect of AM inoculation (Maiti et al., 2011, 2012; Rivera et al., 2007), intentional water stress (García et al., 2009; Polón \& Castro 1999). García et al. (2009) subjected a rice cultivar to water stress in the vegetative phase (50 and 57 days after sowing, in the dry and rainy seasons, respectively) under semi-controlled conditions and found that plants with water stress showed an increase in agricultural yield, which ranged between $30 \%$ and $43 \%$ in the dry and rainy season, respectively.

At 40 DAT and 50 DAT, the plant could be at the beginning and development of the reproductive phase, so the plant metabolism may be being reserved for the change of primordium and flowering, processes which could be affected to a greater extent by the imposition of the reduction of the water supply, with respect to the 30 DAT.

A water deficit imposed on the rice plant in the final period of the vegetative phase (50 DAT, leads to severe water stress, which was evidenced through the values of water potential $(<-160 \mathrm{MPa})$, due to foliar development reached by the plant, which consumes and exchanges a greater amount of water for evapotranspiration. It is possible that this water consumption is very related to the process of translocation of the leaves towards internodes in its first stage and also for the cellular elongation that should occur in the reproductive phase for the emission of the flower spike in the crop, therefore, it causes a decrease of the foliar water potential superior to the treatment with water deficit at 40 DAT and 30 DAT, respectively.

It is important to mention that at this time of evaluation (122 DAT, 25 days before harvest), the plants were in a process characterized by a greater demand for water for metabolite translocation and grain filling (García et al., 2010), as well as by senescence, an aspect that diminishes photosynthesis (Lim et al., 2007) and causes biochemical changes in the plant in order to complete its biological cycle.

The recovery of the plants to the water deficit (122 DAT) indicated the direct participation of the AM in the mechanisms of signaling and adaptation of the plants to the state of stress and recovery of the same. All of the above indicated that the behavior found for $\Psi \mathrm{h}$ was influenced by the AM inoculation, since somehow the water absorption capacity of the plants and presumably the hydraulic conductivity of the root were increased, which was also corroborated in other studies (Dell'Amico et al., 2002; Smith et al., 2010), with different wheat genotypes (Silva-Robledo et al., 2007) and maize (Bárzana et al., 2012).

After the recovery period, according to $\Psi \mathrm{h}$ values, it can be demonstrated the recovery capacity of the plants exposed to water stress, both in the AM as in the non AM plants treatments. In this respect, Polón (2007) reported 
that rice has the capacity to recover from drought, even when water stress imposed can be considered as severe by its duration and intensity. If the water stress is severe, García et al. (2010) indicates that it decreases the yield and can cause the death of the plant. Both criteria suggest that there is no clear picture of how far and how long a rice plant can tolerate drought as an effect of water stress.

To the extent that water stress became more belatedly, it corresponded with the limitation of the growth and development of the rice plant, which could be attributed to a decrease of the entrance of $\mathrm{CO}_{2}$ in the cells and a low efficiency in the use of the light, at the same time could cause the inactivation of the photosynthetic system and therefore, the plants did not produce sufficient assimilates that contributed to the cellular division of the meristematic tissue for the growth of the plant (Mostajeran and Rahimi-Eichi, 2009; Zubarer et al., 2007), and its accumulation for grain filling (García et al., 2010), while increasing ethylene production under these conditions and thus the senescence process (Malik et al., 2003).

The $\Psi \mathrm{h}$ ranges presented were comparable to those proposed for all plants by Hsiao (1973), a proposal that was made from an analysis of published results on the effect of water stress on plants. However, this author defined three degrees of stress to categorize the water status of a plant, taking into account the values of $\Psi \mathrm{h}$ and the relative water content (RWC). RWC is the water content (on a percentage basis) relative to the water content of the same tissue at full turgor (after floating on water to "constant" weight): Light water deficit: When $\Psi$ h is greater than -5 bar or when the RWC is reduced by $8-10 \%$. Moderate water deficit: When the $\Psi$ h is between -5 bar to -12 or -15 bar or when the RWC decreases between 10 and $20 \%$. Severe water deficit: When $\Psi \mathrm{h}$ is less than -15 bar or when RWC decreases by more than $20 \%$.

Other studies related to leaf water potential and irrigation in vine plants (Carbonneau, 1998) proposed five categories of water stress for this crop, which included severe stress at potential less than $0.8 \mathrm{MPa}$. On the other hand, Deloire \& Heyns (2011), Ojeda et al. (2002) and, Williams \& Araujo (2002), proposed four categories and dound that above $0.9 \mathrm{MPa}$, vegetative growth, photosynthesis and grape ripening were inhibited. These works did not apply a mathematical procedure that will substantiate the levels of proposed water potential.

\section{Conclusions}

The rice plants responded differently to water deficiency depending on the time of its imposition and plant phenological status. The arbuscular mycorrhizal symbiosis favored the hydric state of the plant when they are subjected to water deficit, which is evidenced by the water potential and the increase in yield, but this could change depending on the variety, the time of year and the intensity of stress water.

At the later stages of its vegetative phase (50 DAT), the water deficit for a period of 15 days causes caused severe stress, with values of water potential lower than -1.60 MPa, which decrease the yield. The categorization of water deficit stress based on leaf water potential in rice, makes it possible to specify that when plants reach -1.20 $\mathrm{MPa}$, regardless of the developmental stage at which they are, the water sheet must be restored to achieve the recovery of the plants and to reach the highest yields.

The categorization of stress due to water deficit is a tool of high scientific value for the specific case of rice, since this plant has the adaptive capacity to tolerate the presence of a sheet of water throughout its biological cycle and is highly susceptible to water deficit caused by lack of irrigation.

\section{Acknowledgments}

The research was funded by AECID (Grant MAE-AECID 2008/09 260940). 


\section{References}

Aroca, R., Vernieri, P., \& Ruiz-Lozano, J. M. (2008). Mycorrhizal and non-mycorrhizal Lactuca sativa plants exhibit contrasting responses to exogenous ABA during drought stress and recovery. Journal of Experimental Botany, 59(8), $2029-2041$. https://doi.org/10.1093/jxb/ern057

Augé, R. M. (2004). Arbuscular mycorrhizae and soil/plant water relations. Canadian Journal of Soil Science, 84(4), $373-381$. https://doi.org/10.4141/S04-002

Azcón-Bieto, J., \& Talón, M. (2000). Fundamentos de Fisiología Vegetal. 2a Ed. McGraw-Hill.

Bárzana, G., Aroca, R., Paz, J. A., Chaumont, F., Martínez-Ballesta, M. C., Carvajal, M., \& Ruiz-Lozano, J. M. (2012). Arbuscular mycorrhizal symbiosis increases relative apoplastic water flow in roots of the host plant under both wellwatered and drought stress conditions. Annals of Botany, 109(5), 1009-1017. https://doi.org/10.1093/aob/mcs007

Bárzana, G., Aroca, R., \& Ruiz-Lozano, J. M. (2015). Localized and non-localized effects of arbuscular mycorrhizal symbiosis on accumulation of osmolytes and aquaporins and on antioxidant systems in maize plants subjected to total or partial root drying. Plant Cell and Environment, 38(8), 1613-1627. https://doi.org/10.1111/pce.12507

Bernier, J., Atlin, G. N., Serraj, R., Kumar, A., \& Spaner, D. (2008). Breeding upland rice for drought resistance. Journal of the Science of Food and Agriculture, 88(6), 927-939. https://doi.org/10.1002/jsfa.3153

Bohnert, H. J., Nelson, D. E., \& Jensen, R. G. (1995). Adaptations to environmental stresses. American Society of Plant Physiologists. The Plant Cell, 7, 1099-1111.

Bray, E. A. (2004). Genes commonly regulated by water-deficit stress in Arabidopsis thaliana. Journal of Experimental Botany, 55(407), 2331-2341. https://doi.org/10.1093/jxb/erh270

Brunner, I., Herzog, C., Dawes, M. A., Arend, M., \& Sperisen, C. (2015). How tree roots respond to drought. Frontiers in Plant Science, 6(547), 1-16. https://doi.org/10.3389/fpls.2015.00547

Carbonneau, A. (1998). Qualitative aspects. In J. R. Tiercelin (Ed.), Proceedings of the XXVI-Ith World Congress of Vine and Wine (pp. 258-276). Lavoisier Tec et Doc ed.

Cate, R. B., \& Nelson, L. A. (1971). A simple statistical procedure for partitioning soil test correlation data into two classes. Soil Science Society of America Journal, 35(4), 658-659. https://doi.org/10.2136/sssaj1971.03615995003500040048x

Damour, G., Simonneau, T., Cochard, H., \& Urban I. (2010). An overview of models of stomatal conductance at the leaf level. Plant Cell \& Environment, 33(9), 1419-1438.

Degiovanni, V., Martínez, C. P., \& Motta, F. (Eds.) (2010). Producción eco-eficiente del arroz en América Latina. Centro Internacional de Agricultura Tropical. https://doi.org/10.1111/j.1365-3040.2010.02181.x

Dell'Amico, J., Rodríguez, P., Torrecillas, A., Morte, A., \& Sánchez-Blanco M. J. (2002). It influences of the micorrización in the growth and the relationships water of exposed tomato plants to a cycle of drought and recovery. Cultivos Tropicales, 23(1), 29-34.

Deloire, A., Vaudour, E., Carey, V., Bonnardot, V., \& Van Leeuwen, C. (2005). Grapevine responses to terroir, a global approach. Journal International des Science de la Vigne et du Vin, 39(4), 149-162. https://doi.org/10.20870/oenoone.2005.39.4.888 
Deloire, P. A., \& Heyns, D. (2011). The leaf water potentials: Principles, method and thresholds. Wynboer, 265, 119-121.

Duncan, D. B. (1955). Multiple range and multiple F-tests. Biometrics, 11(1), 1-42.

Farooq, M., Hussain, M., \& Siddique, K. H. (2014). Drought stress in wheat during flowering and grain-filling periods. Critical Reviews in Plant Sciences, 33(4), 331-349. https://doi.org/10.1080/073552689.2014.875291

Farooq, M., Wahid, A., Basra, S., \& Islam-ud-Din, M. (2009). Improving water relations and gas exchange with brassinosteroids in rice under drought stress. Journal Agronomy and Crop Science, 195(4), 262-269. https://doi.org/10.1111/j.1439037X.2009.00368.x

Field, C. B., Barros, V. R., Dokken, D. J., Mach, K. J., Mastrandrea, M. D., Bilir, T. E., Chatterjee, M., Ebi, K. L., Estrada, Y. O., Genova, R. C., Girma, B., Kissel, E. S., Levy, A. N., MacCracken, S., Mastrandrea, P. R., \& White L. L. (Eds.), Intergovernmental Panel on Climate Change. (2014). Climate change: Impacts, adaptation, and vulnerability Part A: Global and sectoral aspects. Contribution of working group II to the fifth assessment report of the intergovernmental panel on climate change. Cambridge University Press.

García, A., Dorado, M., Pérez, I., \& Montilla, E. (2009). Dry mass accumulation of different organs of the rice plant under water deficit conditions. Agronomía Tropical, 59(1), 15-24.

García, A., Dorado, M., Pérez, I., \& Montilla, E. (2010). Effect of water deficit on the distribution of photoassimilate in rice plants (Oryza sativa L.). Interciencia, 35(1), 47-54. https://www.cabdirect.org/cabdirect/abstract/20103112596

Giovannetti, M., \& Mosse, B. (1980). An evaluation of techniques for measuring vesicular arbuscular infection in roots. New Phytologist, 84(3), 489-500. https://doi.org/10.1111/j.1469-8137.1980.tb04556.x

Golldack, D., Li, C., Mohan, H., \& Probst, N. (2014). Tolerance to drought and salt stress in plants: unraveling the signaling networks. Frontiers in Plant Science, 2014, Article 151. https://doi.org/10.3389/fpls.2014.00151

Hattori, Y., Nagai, K., \& Ashikari. (2011). Rice growth adapting to deepwater. Current Opinion in Plant Biology, 14(1), $100-105$. https://doi.org/10.1016/j.pbi.2010.09.008

Hsiao, T. C. (1973). Plant responses to water stress. Annual Review Plant Physiology, 24, 519-570. https://doi.org/10.1146/ annurev.pp.24.060173.002511

International Rice Research Institute. (2013). Standard evaluation system for rice ( $\left.5^{\text {th }} \mathrm{Ed}\right)$. International Rice Research Institute. http://www.clrri.org/ver2/uploads/SES_5th_edition.pdf

Ishii, T., Shrestha, Y., H, Marsumoto, I., \& Kadoya, K. (1996). Effect of ethylene on the Growth of vesicular-arbuscular mycorrhizal fungi and on the mycorrhizal formation of trifoliate orange roots. Journal of the Japanese Society for Horticultural Science, 65(3), 2525-259. https://doi.org/10.2503/jjshs.65.525

Kamoshita, A., Babu, R. C, Boopathi, N. M., \& Fukai, S. (2008). Phenotypic and genotypic analysis of drought-resistance traits for development of rice cultivars adapted to rainfed environments. Field Crops Research, 109(1-3), 1-23. https://doi. org/10.1016/j.fcr.2008.06.010

Khush, G. S. (2003). Productivity improvements in rice. Nutrition Reviews, 61(6), 114-116. https://doi.org/10.1301/nr.2003. jun.S114-S116

Lehto, T., \& Zwiazek, J. J. (2011). Ectomycorrhizas and water relations of trees: a review. Mycorrhiza, 21, 71-90. https://doi. org/10.1007/s00572-010-0348-9 
Li, H., Ye, Z. H., Chan, W. F., Chen, X. W., Wu, F. Y., Wu, S. C., \& Wong, M. H. (2011). Can arbuscular mycorrhizal fungi improve grain yield, as uptake and tolerance of rice grown under aerobic conditions? Environmental Pollution, 159(10), 2537-2545. https://doi.org/10.1016/j.envpol.2011.06.017

Lim, P. O., Kim, H. J., \& Nam, H. G. (2007). Leaf senescence. Annual Review of Plant Biology, 58, 115-136. https://doi. org/10.1146/annurev.arplant.57.032905.105316

Ma, Y. H., Ma, F. W., Zhang, J. K., Li, M. J., Wang, Y. H \& Liang, D. (2008). Effects of high temperature on activities and gene expression of enzymes involved in ascorbate-glutathione cycle in apple leaves. Plant Science, 175(6), 761-6. https:// doi.org/10.1016/j.plantsci.2008.07.010

Maiti, D., Toppo, N. N., \& Variar, M. (2011). Integration of crop rotation and arbuscular mycorrhiza (AM) inoculum application for enhancing AM activity to improve phosphorus nutrition and yield of upland rice (Oryza sativa L.). Mycorrhiza, 21(8), 659. https://doi.org/10.1007/s00572-011-0376-0

Maiti, D., Singh, R. K., \& Variar, M. (2012). Rice-based crop rotation for enhancing native arbuscular mycorrhizal (AM) activity to improve phosphorus nutrition of upland rice (Oryza sativa L.). Biology and Fertility of Soils, 48, 67-73. https://doi. org/10.1007/s00374-011-0609-6

Malik, AI., Colmer, T. D., Lambers H., \& Schortemeyer, M. (2003). Aerenchyma formation and radial $\mathrm{O}_{2}$ loss along adventitious roots of wheat with only the apical root portion exposed to $\mathrm{O}_{2}$ deficiency. Plant Cell \& Environment, 26(10), 17131722. https://doi.org/10.1046/j.1365-3040.2003.01089.xl

Mostajeran, A., \&. Rahimi-Eichi, V. (2009). Effects of drought stress on growth and yield of rice (Oryza sativa L.) cultivars and accumulation of proline and soluble sugars in sheath and blades of their different ages leaves. American-Eurasian Journal Agriculture and Environmental Science, 5(2), 264-272.

Oladosu, Y., Rafii, M. Y., Samuel, C., Fatai, A., Magaji, U., Kareem, I., Kamarudin, Z. S., Muhammad, I., \& Kolapo, K. (2019). Drought Resistance in Rice from Conventional to Molecular Breeding: A Review. International journal of molecular sciences, 20(14), 3519. https://doi.org/10.3390/ijms20143519

Ojeda, H., Andary, C., Kraeva, E., Carbonneau, A., \& Deloire, A. (2002). Influence of pre- and post-véraison water deficit on synthesis and concentration of skin phenolic compounds during berry growth of Vitis vinifera L, cv Shiraz. American Journal of Enology and Viticulture, 53(4), 261-267.

Osakabe, Y., Osakabe, K., Shinozaki, K., \& Tran, L. (2014). Response of plants to water stress. Frontiers in Plant Science, 2014, Article 86. https://doi.org/10.3389/fpls.2014.00086

Pérez, N., González, M. C., Cristo, E., Díaz S. H., Díaz, E. C., \& Blanco, G. (2018). Cultivares cubanos de arroz. Ediciones INCA.

Phillips, J. M., \& Hayman, D. S. (1970). Improve procedures for cleaning root and staining parasitic and vesicular-arbuscular mycorrhizal fungi for rapid assessment of infections. Tranfer Britannic Micology Society, 55, 158-161. https://doi.org/ https://doi.org/10.1016/S0007-1536(70)80110-3

Polón, R. (2007). Study of different handlings of water in the cultivation of the rice (Oryza sativa L.) and their influence in the germination, the dry mass, the height of the plant and the yield. Cultivos Tropicales, 28(2), 101-103.

Polón, R., \& Castro, R. (1999). Application of the water stress like alternative to increase the yield in the cultivation of the rice (Oryza sativa L.). Cultivos Tropicales, 20(3), 37-39. 
Porcel R., \& Ruiz-Lozano, J. M. (2004). Arbuscular mycorrhizal influence on leaf water potential, solute accumulation and oxidative stress in soybean plants subjected to drought stress. Journal of Experimental Botany, 55(403), 743-50. https://doi.org/10.1093/jxb/erh188

Pozo, M. J., López-Róez, J. A., Azcón-Aguilar, C., \& García-Garrido, J. M. (2015). Phytohormones as integrators of environmental signals in the regulation of mycorrhizal symbioses. New Phytologist, 205(4), 1431-1436. https://doi. org/10.1111/nph.13252

Rivera, R., Fernández, F., Fernández, K., Ruiz, L., Sánchez, C., \& Riera, M. (2007). Advances in the management of effective arbuscular symbiosis in tropical ecosystems. In C. Hamel, \& C. Plenchette (Eds.), Mycorrhizae in crop productions (pp. 151-195). The Haworth Press, Inc.

Ruiz-Lozano, J. M., Porcel, R., Bárzana, G., Azcón-Aguilar, R., \& Aroca, R. (2012). Contribution of arbuscular mycorrhizal symbiosis to plant drought tolerance. State of the art. In. R. Aroca (Ed.), Plant Responses to Drought Stress: From Morphological to Molecular Features (pp. 335-362). Springer-Verlag.

Ruiz-Sánchez, M., Armada, E., Muñoz, Y., García de Salamone, I., Aroca, R. Ruiz-Lozano, J. M., \& Azcón-Aguilar, R. (2011). Azospirillum and arbuscular mycorrhizal colonization enhance rice growth and physiological traits under well-watered and drought conditions. Journal of Plant Physiology, 168(10), 1031-1037. https://doi.org/10.1016/j.jplph.2010.12.019

Ruiz-Sánchez, M., Aroca, R., Muñoz, Y., Polón, R., \& Ruiz-Lozano, J. M. (2010). The arbuscular mycorrhizal symbiosis enhances the photosynthetic efficiency and the antioxidative response of rice plants subjected to drought stress. Journal of Plant Physiology, 167(11), 862-869. https://doi.org/10.1016/j.jplph.2010.01.018

Ruiz-Sánchez, M, Geada, D., Muñoz, Y., Martínez, A., Santana, Y., Benítez, M., Aroca, R., \& Ruiz-Lozano, J. M. (2015). Mycorrhizae arbuscular symbiosis in rice plants (Oryza sativa L.) under water stress. Part II Biochemical response. Culivos Tropicales, 36(3), 88-95.

Serraj, R., McNally, I. K., Slamet-Loedin, I., Kohli, A., Haefele, M. S., Atlin, G., \& Kumar A. (2011). Drought resistance improvement in rice: an integrated genetic and resources management strategy. Plant Production Science, 14(1), 1-14. https://doi.org/10.1626/pps.14.1

Shinozaki, K., \& Yamaguchi-Shinozaki, K. (2006). Transcriptional regulatory networks in cellular responses and tolerance to dehydration and cold stresses. Annual Review of Plant Biology, 57, 781-803. https://doi.org/10.1146/annurev. arplant.57.032905.105444

Silva-Robledo H, Ortiz-Lizana M., \& Acevedo-Hinojosa, E. (2007). Hydric relationships and osmotic adjustment in wheat. Agrociencia, 41(1), 23-34.

Singhal, P., Jan, A. T., Azam, M., \& Haq, Q. M. R. (2016). Plant abiotic stress: A prospective strategy of exploiting promoters as alternative to overcome the escalating burden. Frontiers of Life Science, 9(1), 52-63. https://doi.org/10.1080/215 53769.2015.1077478

Smith, S. E, Facelli E, Pope, S., \& Smith, F. A. (2010). Plant performance in stressful environments: interpreting new and established knowledge of the roles of arbuscular mycorrhizas. Plant and Soil, 326, 3-20. https://doi.org/10.1007/ s11104-009-9981-5

Taiz, L., \& Zeiger, E. (2006). Plant physiology (4 ${ }^{\text {th }}$ Ed.). Sinauer Associates, Inc, Publishers.

Trenberth, K. E., Dai A., Van Der Schrier G., Jones P. D., Barichivich J., Briffa K. R., \& Sheffield J. (2014). Global warming and changes in drought. Nature Climate Change, 4, 17-22. 
Vallino M., Fiorilli, V., \& Bonfante, P. (2014). Rice flooding negatively impacts root branching and arbuscular mycorrhizal colonization, but not fungal viability. Plant Cell and Environment, 37(3), 557-572. https://doi.org/10.1111/pce.12177

Vallino, M., Greppi, D., Novero, M., Bonfante, P., \& Lupotto, E. (2009). Rice root colonization by mycorrhizal and endophytic fungi in aerobic soil. Annals of Applied Biology, 154(2), 195-204. https://doi.org/10.1111/j.1744-7348.2008.00286.x

Williams, L. E., \& Araujo, F. J. (2002). Correlations among leaf, midday leaf and midday stem water potential and their correlations with other measures of soil and plant water status in Vitis vinifera. Journal of the American Society for Horticultural Science, 127(3), 448-454. https://doi.org/10.21273/JASHS.127.3.448

Zubarer, M. A., Chowdhury, A., Islam, M. Z., Ahmed, T., \& Hasan, M. A. (2007). Effects of water stress on growth and yield attributes of Aman rice genotypes. International Journal of Sustainable Crop Production, 2(6), 25-30. 